\title{
PENERAPAN MODEL PEMBELAJARAN GIVING QUESTION AND GETTING ANSWER TERHADAP KEMAMPUAN KOMUNIKASI MATEMATIS SISWA
}

\author{
Asep Sujana ${ }^{1}$, Rika Cahyawati ${ }^{2}$ \\ FKIP Unma Banten, ikasep123@gmail.com \\ FKIP Unma Banten, rikacahyaw @ gmail.com
}

\begin{abstract}
Abstrak
Penelitian ini bertujuan untuk menganalisis kemampuan awal, kemampuan akhir, serta peningkatan kemampuan komunikasi matematis siswa melalui model pembelajaran Giving Question and Getting Answer. Penelitian di dilaksanakan di SMP Negeri 1 Cinangka tahun pelajaran 2017/2018. Metode yang digunakan adalah quasi eksperimen dengan desan pretest-posttest control group design. Pengambilan sampel dilakukan dengan menggunakan cluster random sampling. Sampel penelitian berjumlah 33 siswa untuk kelas eksperimen dan 36 siswa untuk kelas kontrol. Peningkatan dihitung dengan menggunakan N-Gain. Data dianalisis menggunakan uji-t. hasil penelitian menunjukan bahwa kemampuan awal komunikasi matematis siswa kelas ekperimen dan kelas kontrol adalah sama. Kemampuan akhir komunikasi matematis siswa kelas ekperimen lebih tinggi daripada kelas kontrol. Peningkatan kemampuan komunikasi matematis siswa yang diterapkan model pembelajaran Giving Question and Getting Answer lebih tinggi daripada siswa yang diterapkan model pembelajaran konvensional. Dengan demikian, penerapan model pembelajaran Giving Question and Getting Answer dapat meningkatkan kemampuan komunikasi matematis siswa kelas VIII SMP Negeri 1 Cinangka.
\end{abstract}

Kata kunci: Kemampuan Komunikasi Matematis Siswa, Model Pembelajaran Giving Question And Getting Answer

\begin{abstract}
The research aims to analyse the students pre-ability, post-ability, and improvement of mathematical communication ability towards Giving Question and Getting Answer technique. The research is conducted in SMP Negeri 1 Cinangka academic year 2017/2018. The research method is quasi-experiment with pretest and posttest control group design. The research sample is 33 students for experimental class and 36 students for control class. The improvement is calculated by using $N$-Gain. The data analysis uses T-Test. The research result show that the student pre-ability of mathematical communication for experimental and control class is equal. The students post-ability of mathematical communication for experimental class is higher than the students who is applied by conventional technique. Therefor, the implementation of Giving Question and Getting Answer technique can improve the students mathematical communication ability for grade VIII SMP Negeri 1 Cinangka.
\end{abstract}


Keywords: Students mathematical communication ability, Giving Question and Getting Answer

\section{PENDAHULUAN}

Pendidikan merupakan sarana penting untuk meningkatkan kualitas sumber daya manusia (SDM) dalam menjamin keberlangsungan pembangunan suatu bangsa. Oleh karena itu, Indonesia menjadi negara yang menempatkan pendidikan pada tempat yang utama.

Fungsi dan tujuan pendidikan nasional tertuang dalam Undang-Undang Republik Indonesia Nomor 20 Tahun 2003 Pasal 3 yaitu Pendidikan nasional berfungsi mengembangkan dan membentuk watak serta peradaban bangsa yang bermartabat dalam rangka mencerdaskan kehidupan bangsa, bertujuan untuk berkembangnya potensi peserta didik agar menjadi manusia yang beriman dan bertakwa kepada Tuhan Yang Maha Esa, berakhlak mulia, sehat, berilmu, cakap, kreatif, mandiri, dan menjadi warga negara yang demokratis serta bertanggung jawab. Undang-undang tersebut menyatakan bahwa pendidikan di Indonesia merupakan sektor yang penting. Salah satu bagian yang memegang peran penting dalam dunia pendidikan adalah matematika. Matematika merupakan induk dari segala ilmu dalam pendidikan. Oleh sebab itu, semua siswa diwajibkan mempelajari matematika.

Matematika juga merupakan salah satu alat bahasa yang digunakan untuk berkomunikasi. Karena hampir semua aspek berhubungan dengan matematika, dimana matematika merupakan bagian dari ilmu pengetahuan yang sangat penting dalam pendidikan, sehingga mata pelajaran matematikadiajarkan pada semua tingkat pendidikan, mulai jenjang pendidikan rendah sampai jenjang pendidikan tinggi.

Susanto (2013:183) berpendapat bahwa matematika merupakan ide-ide abstrak yang berisi simbol-simbol, maka konsep-konsep matematika harus dipahami terlebih dahulu sebelum memanipulasi simbol-simbol itu. Selain itu, Johnson dan Rising (1972) yang dikutip oleh Suherman (2001:19) mengatakan bahwa matematika adalah pola pikir, pola pengorganisasikan, pembuktian yang logik, matematika itu adalah bahasa yang menggunakan istilah yang didefinisikan dengan cermat, jelas, dan akurat, representasinya dengan simbol yang padat, lebih berupa bahasa simbol mengenai ide daripada mengenai bunyi.

Tujuan diberikannya mata pelajaran matematika di sekolah menurut Permendiknas Nomor 22 Tahun 2006 adalah agar peserta didik memiliki kemampuan sebagai berikut: (1) Memahami konsep matematika, menjelaskan ketertarikan antar konsep dan mengaplikasikan konsep atau algoritma, secara luwes, akurat, dan tepat, dalam pemecahan masalah, (2) Menggunakan penalaran pada pola dan sifat, melakukan manipulasi matematika dalam membuat generalisasi, menyusun bukti, atau menjelaskan gagasan dan pernyataan matematika, (3) Memecahkan masalah yang meliputi kemampuan memahami masalah, merancang model matematika, menyelesaikan model dan menafsirkan solusi yang diperoleh, (4) Mengomunikasikan gagasan dengan simbol, tabel, diagram, atau media lain untuk memperjelas keadaan atau masalah dan (5) Memiliki sikap menghargai kegunaan matematika dalam kehidupan, yaitu memiliki rasa ingin tahu, perhatian, dan minat dalam mempelajari matematika, serta sikap ulet dan percaya diri dalam pemecahan masalah.

Dari tujuan di atas, beberapa kemampuan matematis yang ingin dikembangkan antara lain pemahaman konsep, penalaran, koneksi, komunikasi matematis, dan pemecahan masalah. Namun pada kenyataannya kemampuan 
matematis siswa Indonesia tidak sesuai dengan tujuan yang telah dirumuskan. Kemampuan matematis siswa Indonesia bisa dikatakan memprihatinkan karena tertinggal dengan negara-negara lain.

Berbagai penilaian terhadap matematika muncul, sebagai contoh adalah PISA, Indonesia sendiri telah berpartisipasi dalam Programme for International Student Assesment (PISA) bahkan sejak tahun 2000 dimana PISA pertama kali dilaksanakan. PISA merupakan skala penilaian internasional yang fokus di bidang membaca (reading literacy), matematika (mathematical literacy) serta sains (sciencetific literacy). Adapun tujuan dari PISA tersebut adalah mengetahui sejauh manakah kemampuan siswa (anak berumur 15 tahun) bisa menerapkan pengetahuan yang meraka pelajari disekolah.

Iswadi (2016) dalam artikelnya mengatakan bahwa hasil tes dan survey (PISA) pada tahun 2015 melibatkan 540.000 siswa di 70 negara, dianalisa dengan hati-hati dan lengkap sehingga survey dan tes tahun berjalan baru bisa didapatkan pada akhir tahun berikutnya. Jadi hasil literasi PISA 2015 baru bisa dirilis pada bulan Desember 2016. Pada web OECD (Organisation for Economic Cooperation and Development atau Organisasi untuk Kerjasama dan Pengembangan Ekonomi) dapat dilihat data yang berlimpah yang berkaitan dengan hasil tes dan survey PISA. Pada tes dan survey PISA 2015 diperoleh data bahwa Singapura adalah negara yang menduduki peringkat 1 untuk ketiga materi sains, membaca, dan matematika.

Dari hasil tes dan evaluasi PISA 2015 performa siswa-siswi Indonesia masih tergolong rendah. Berturut-turut rata-rata skor pencapaian siswa-siswi Indonesia untuk sains, membaca, dan matematika berada di peringkat 62, 61, dan 63 dari 69 negara yang dievaluasi. Peringkat dan rata-rata skor Indonesia tersebut tidak berbeda jauh dengan hasil tes dan survey PISA terdahulu pada tahun 2012 yang juga berada pada kelompok penguasaan materi yang rendah. Selain itu, Oktaviyanthi, Agus dan Supriani (2015) mengutarakan dalam hasil kajian awalnya bahwa pengetahuan guru mengenai kemampuan literasi matematik peserta didiknya menjadi pertimbangan dalam merumuskan, menyusun dan mengembangkan metode pembelajaran dan instrumen penilaian hasil belajar.

Menurut Syamsuddin (2015:156) proses belajar mengajar dapat diartikan sebagai salah satu rangkaian interaksi antara siswa dan guru dalam rangka mencapai tujuannya. Surya (2004:51) menyimpulkan bahwa perilaku belajar mengajar yang terjadi pada peserta didik (siswa) dapat dikenal dengan baik dalam proses maupun hasilnya. Proses belajar dapat terjadi apabila individu merasakan adanya kebutuhan dalam dirinya yang tidak dapat dipenuhi dengan cara-cara yang telah ada seperti refleks atau kebiasaan. Dalam proses pembelajaran akan selalu terjadi peristiwa saling berhubungan atau komunikasi antar pemberi pesan (guru) yang memiliki sejumlah unsur dan pesan yang ingin disampaikan, serta cara menyampaikan pesan kepada siswa sebagai penerima pesan. Dalam konteks pembelajaran matematika yang berpusat pada siswa, pemberi pesan tidak terbatas oleh guru saja melainkan dapat dilakukan oleh siswa maupun media lain. Banyak persoalan yang disampaikan dengan bahasa matematika, misalnya dengan menyajikan persoalan atau masalah ke dalam model matematika yang dapat berupa diagram, persamaan matematika, grafik dan tabel. 
Berdasarkan hasil observasi di SMP Negeri 1 Cinangka kebanyakan siswa berpendapat bahwa matematika merupakan mata pelajaran yang sulit. Selain itu juga, pada proses pembelajaran matematika yang sering dijumpai adanya kencenderungan siswa tidak mau bertanya karena sulit dalam menyampaikan pertanyaan ke dalam bahasa matematika meskipun ia belum memahami materi pelajaran matematika yang diajarkan tersebut. Bahkan kebanyakan siswa yang cerdas dalam matematika sering kurang mampu menyampaikan pemikirannya. Seolah-olah mereka tidak mau berbagi ilmu dengan yang lainnya. Jika hal ini terus dibiarkan maka siswa akan semakin kurang mampu berkomunikasi menggunakan matematika.

Hal itu terbukti melalui hasil ulangan dari siswa kelas VIII yang berjumlah 218 siswa, 70\% dari data yang didapatkan hasil ulangan dari seluruh siswa dari kelas VIII A sampai VIII G rata-rata dibawah 50. Sedangkan 30\% memperoleh hasil diatas 50. Hasil ulangan yang rendah tersebut salah satunya disebabkan oleh kurangnya kemampuan komunikasi matematis siswa.

Rendahnya kemampuan siswa dalam mempelajari matematika juga dipengaruhi oleh kurangnya partisipasi aktif siswa dalam pembelajaran di kelas, dan siswa cenderung tidak berani mengungkapkan atau menjelaskan ide-ide mereka jika diberi soal yang berkaitan dengan mengungkapkan pendapat. Hal ini sangat menghambat siswa untuk dapat menyelesaikan permasalahan yang ada. Partisipasi ini berhubungan erat dengan kemampuan komunikasi matematis siswa. Rendahnya kemampuan komunikasi matematis ini mengakibatkan siswa sulit untuk mencerna soal-soal yang diberikan sehingga mereka tidak bisa memecahkan masalah tersebut. Seorang siswa yang memiliki kemampuan komunikasi yang baik akan dapat dengan mudah mengambil suatu langkah untuk menyelesaikan sebuah persoalan. Selain itu, banyak siswa yang tidak mampu menyatakan benda nyata, gambar dan diagram ke dalam ide matematika, dan juga tidak mampu menyatakan peristiwa sehari-hari dalam bahasa atau simbol matematis.

Komunikasi matematik menurut Hendriana, Sumarmo dan Rohaeti (2013:36) merupakan kemampuan matematik esensial yang tercantum dalam kurikulum matematika sekolah menengah. Komponen tujuan pembelajaran matematika tersebut antara lain: dapat mengomunikasikan gagasan dan simbol, tabel, diagram, atau ekspresi matematik untuk memperjelas keadaan suatu masalah, dan memiliki sikap menghargai kegunaan matematika dalam kehidupan, sikap rasa ingin tahu, perhatian, dan minat dalam mempelajari matematika, serta sikap ulet dan percaya diri dalam pemecahan masalah.

Selain itu pengertian komunikasi matematis juga dikemukakan oleh Susanto (2013: 213) adalah suatu peristiwa dialog atau saling hubungan yang terjadi di lingkungan kelas, dimana terjadi pengalihan pesan, dan pesan yang dialihkan berisikan tentang materi matematika yang dipelajari siswa, misalnya berupa konsep, rumus, atau strategi penyelesaian suatu masalah. Adapun indikator kemampuan komunikasi matematis yaitu: (1) kemampuan mengekspresikan ideide matematika melalui lisan, tulisan, dan mendemonstrasikannya serta menggambarkan secara visual, (2) kemampuan memahami, menginterpretasikan, dan mengevaluasi ide-ide matematika baik secara lisan, maupun dalam bentuk visual lainnya dan (3) kemampuan menggunakan istilah, notasi matematika dan struktur-strukturnya untuk menyajikan ide, menggambarkan hubungan dan model situasi. 
Dari uraian di atas dapat disimpulkan bahwa kemampuan komunikasi matematis mempunyai peran penting dalam membangun pengetahuan matematika serta mengembangkan pemahaman matematika siswa selain itu dapat berpengaruh terhadap prestasi siswa. Untuk itu perlu adanya upaya untuk meningkatkan kemampuan komunikasi matematis siswa. Salah satu upaya yang dapat dilakukan adalah dengan menggunakan model pembelajaran yang tepat. Model pembelajaran yang dikemukakan oleh Syamsuddin (2015: 65) adalah pola yang digunakan sebagai pedoman dalam merencanakan pembelajaran di kelas maupun tutorial.

Keberhasilan suatu strategi pembelajaran di dalam kelas tergantung pada kepiawaian guru dalam menggunakan model, metode, teknik, dan strategi pembelajaran (Oktaviyanthi dan Herman, 2016; Oktaviyanthi, Agus dan Safaah, 2017). Akan tetapi proses pembelajaran matematika di sekolah masih menggunakan pembelajaran konvensional. Pada pembelajaran ini suasana kelas cenderung teacher-centered sehingga siswa menjadi pasif. Pertanyaan dari siswa jarang muncul, berorientasi pada satu jawaban yang benar, dan aktivitas kelas yang dilakukan hanyalah mencatat dan menyalin. Akibatnya siswa menjadi kurang aktif dan pembelajaran menjadi hal yang membosankan bagi siswa. Sehingga dapat menurunkan motivasi belajar dan inisiatif siswa untuk bertanya dan mengemukakan idenya. Jadi, masalah yang dihadapi dalam dunia pendidikan adalah masalah lemahnya proses pembelajaran. Dalam proses pembelajaran siswa kurang didorong untuk mengembangkan keterampilan berpikir (Oktaviyanthi dan Dahlan, 2018). Dengan demikian, interaksi antara guru dan siswa dalam proses pembelajaran belum maksimal.

Guru dituntut untuk membuat siswa dapat dengan mudah memahami matematika baik secara nyata maupun secara penerapan, seorang guru dituntut untuk mempunyai komunikasi yang baik dalam menyampaikan masalah serta solusi (Oktaviyanthi, Safaah dan Agus, 2017). Oleh karenanya, matematika bisa disampaikan oleh guru kepada siswa harus menggunakan metode-metode yang baik agar mata pelajaran bisa terkomunikasikan dengan baik. Tidak hanya guru terhadap siswa namun juga terhadap sesama siswa.

Bertanya dan menjawab pertanyaan antara siswa yang satu dengan siswa yang lain merupakan salah satu kegiatan pembelajaran yang memungkinkan untuk meningkatkan kemampuan komunikasi matematis siswa. Model pembelajaran Giving Question and Getting Answer merupakan model pembelajaran yang melatih siswa memiliki keterampilan bertanya dan menjawab pertanyaan terhadap peninjauan kembali materi yang telah diajarkan. Dengan model pembelajaran ini akan melatih siswa memiliki keterampilan bertanya dan menjawab pertanyaan untuk mengingat kembali apa yang dipelajari dalam setiap topik pelajaran. Pembelajaran aktif tipe Giving Question and Getting Answer diharapkan mampu membuat suasana lebih menarik dan lebih menyenangkan bagi siswa dalam mempelajari matematika serta mampu meningkatkan kemampuan komunikasi matematis siswa. Untuk itu, peneliti ingin melakukan penelitian tentang Penerapan Model Pembelajaran Giving Question And Getting Answer terhadap Kemampuan Komunikasi Matematis Siswa Kelas VIII SMP Negeri 1 Cinangka.

Berdasarkan rumusan masalah di atas, yang menjadi tujuan dari penelitian ini yaitu penerapan model pembelajaran Giving Question and Getting Answer dapat meningkatkan kemampuan komunikasi matematis siswa kelas VIII SMP Negeri 1 Cinangka. 


\section{METODE PENELITIAN}

Penelitian ini menggunakan penelitian semu (quasi eksperiment). Dalam penelitian ini terdapat dua kelas yaitu kelas eksperimen dan kelas kontrol. Kelas eksperimen diberi perlakuan dengan menggunakan model pembelajaran Giving Question and Getting Answer dan kelas kontrol diberi perlakuan dengan model pembelajaran konvensional. Kedua kelas diasumsikan sama dalam semua segi dan hanya berbeda dalam pemberian model pembelajaran.

Desain penelitian yang digunakan adalah Pretest-Posttest Control Group Design. Sugiyono (2015:113) mengemukakan bahwa dalam desain ini terdapat dua kelompok yang dipilih secara random, kemudian diberi pretest untuk mengetahui keadaan awal adakah perbedaan antara kelompok eksperimen dan kelompok kontrol. Rancangan penelitian tersebut dinyatakan sebagai berikut:

Tabel 1. Rancangan Penelitian

\begin{tabular}{cccc}
\hline Kelompok & Pretest & Perlakuan & Posttest \\
\hline $\mathrm{KE}$ & $\mathrm{O}_{1}$ & $\mathrm{X}_{1}$ & $\mathrm{O}_{2}$ \\
$\mathrm{KK}$ & $\mathrm{O}_{1}$ & $\mathrm{X}_{2}$ & $\mathrm{O}_{2}$ \\
\hline
\end{tabular}

Keterangan

KE : Kelas Eksperimen

KK : Kelas Kontrol

$\mathrm{O}_{1} \quad$ : Pretest

$\mathrm{O}_{2} \quad$ : Posttest

$\mathrm{X}_{1} \quad$ : Pembelajaran dengan Menggunakan Giving Question and Getting Answer

$\mathrm{X}_{2} \quad$ : Pembelajaran Konvensional

Penelitian ini dilaksanakan di SMP Negeri Cinangka Desa Karang Suraga Kecamatan Cinangka Kabupaten Serang tahun pelajaran 2017/2018. Dimana penelitian tersebut akan dilaksanakan di kelas VIII F sebagai kelas eksperimen yang menggunakan model pembelajaran Giving Question and Getting Answer dan VIII $G$ sebagai kelas kontrol yang menggunakan model pembelajaran konvensional dengan pokok bahasan Aljabar. Model pembelajaran Giving Question and Getting Answerdikembangkan untuk melatih peserta didik memiliki kemampuan dan keterampilan bertanya dan menjawab pertanyaan, sedangkan model pembelajaran konvensional dimana pada pembelajaran ini suasana kelas cenderung teacher-centered sehingga siswa menjadi pasif.

Pada pertemuan pertama, kedua kelas diberikan pretest sedangkan pada pertemuan terakhir kedua kelas diberikan posttest untuk mengukur kemampuan komunikasi matematis siswa. Tes yang diberikan pada kedua kelas tersebut isinya sama sehingga hasilnya dapat digunakan untuk membandingkan kemampuan komunikasi matematis siswa antara kelas ekperimen dan kelas kontrol.

\section{HASIL}

Pada bab ini akan dikemukakan data hasil penelitian yang telah dilakukan, berikut uraian dan temuan selama penelitian. Penelitian ini bertujuan untuk mengetahui peningkatan kemampuan komunikasi matematis siswa kelas VIII SMP Negeri 1 Cinangka melalui model pembelajaran Giving Question and Getting Answer. Dalam penelitian ini digunakan dua kelas yaitu kelas eksperimen sebagai kelas yang mendapatkan model pembelajaran Giving Question and 
Getting Answer dan kelas kontrol yang mendapatkan model pembelajaran konvensional.

Proses penelitian dilakukan selama sebulan yang dimulai pada tanggal 7 Agustus dan berakhir tanggal 7 September 2017. Dalam penelitian ini yang menjadi populasi adalah seluruh kelas VIII SMP Negeri 1 Cinangka. Dari tujuh kelas yang ada, yakni kelas VIII A sampai kelas VIII G. kelas VIII F sebagai kelas eksperimen dan kelas VIII G sebagai kelas kontrol. Kedua kelas tersebut diberikan tes awal (pretest) untuk melihat kemampuan awal kedua kelas dan tes akhir (posttest) untuk melihat kemampuan siswa setelah diberi perlakuan.

\section{A. Deskripsi Data}

Deskripsi data dilakukan untuk dapat memperoleh kesimpulan dalam pelaksanaan penelitian, maka data yang telah diperoleh selanjutnya adalah mengolah data agar skor yang telah diperoleh mempunyai arti. Pengolahan data dalam suatu penelitian dilakukan untuk menemukan jawaban rumusan yang telah diajukan sebelumnya.

Data yang diperoleh dari penelitian ini berupa informasi data tes serta temuan lain dilapangan, data tersebut dianalisis untuk menjawab rumusanrumusan masalah dan untuk membuktikan hipotesis yang diajukan. Untuk mengetahui kemampuan komunikasi matematis siswa, maka diberikan tes berupa tes uraian yang berjumlah 5 butir soal. Tes ini diberikan sebelum dan sesudah pembelajaran berlangsung.

\section{Deskripsi Data Pretest}

Pretest diberikan kepada kelas eksperimen dan kelas kontrol sebelum kegiatan belajar mengajar dilakukan. Dari hasil penelitian yang dilakukan pada tanggal 7 Agustus sampai tanggal 7 september 2017 didapat data pretest pada kelas eksperimen dan kelas kontrol sebagai berikut:

Tabel 2. Deskripsi Data Pretest

\begin{tabular}{cccccccc}
\hline & & \multicolumn{6}{c}{ Nilai } \\
\cline { 3 - 6 } No & Kelas & N & $\begin{array}{c}\text { Nilai } \\
\text { Minimum }\end{array}$ & $\begin{array}{c}\text { Nilai } \\
\text { Maksimum }\end{array}$ & Rerata & Variansi & $\begin{array}{c}\text { Standar } \\
\text { Deviasi }\end{array}$ \\
\hline 1 & Eksperimen & 33 & 5 & 35 & 21,67 & 93,229 & 9,656 \\
2 & Kontrol & 36 & 5 & 35 & 22,64 & 73,552 & 8,576 \\
\hline
\end{tabular}

Berdasarkan tabel di atas, dapat dilihat jumlah responden $(\mathrm{N})$ pada kelas eksperimen sebanyak 33 siswa, rerata kelas ekperimen adalah 21,67, nilai minimum yang diperoleh sebesar 5 dan nilai maksimum sebesar 35 . Sedangkan untuk kelas kontrol jumlah responden sebanyak 36, rerata kelas kontrol sebesar 22,64, nilai minimum dan nilai maksimum berturut-turut adalah 5 dan 35. Sementara itu variansi yang diperoleh kelas eksperimen yaitu 93,229 dengan standar deviasi 9,656, sedangkan variansi yang diperoleh kelas kontrol yaitu 73,552 dengan standar deviasi sebesar 8,576. Dengan demikian, dapat dikatakan bahwa penyebaran data disekitar rerata untuk kelas eksperimen lebih besar daripada kelas kontrol. Hal ini menunjukan bahwa data-data untuk kelas eksperimen lebih tersebar luas, sedangkan kelas kontrol lebih terkumpul.

Hasil data rerata pretest yang didapatkan pada kelas eksperimen maupun kelas kontrol dilihat pada gambar 1. Berdasarkan diagram batang pada gambar 1 tersebut, rerata pretest kelas kontrol lebih besar dari rerata kelas eksperimen. Namun perbedaan tersebut tidak terpaut jauh, sehingga kemampuan antar kedua kelas sebelum diberikan perlakuan dapat dikatakan sama. 


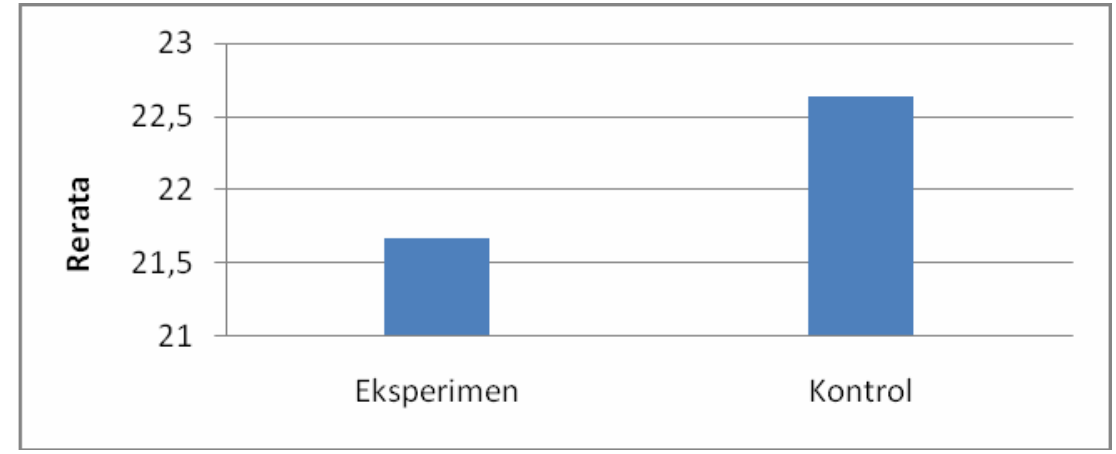

Gambar 1. Diagram Batang Skor Rerata Pretest

2. Deskripsi Data Posttest

Posttest diberikan sesudah kegiatan belajar mengajar. Berdasarkan penelitian yang dilakukan didapatkan data rerata posttest pada kelas eksperimen dan kelas kontrol sebagai berikut:

Tabel 3. Deskripsi Data Posttest

\begin{tabular}{cccccccc}
\hline \multirow{2}{*}{ No } & Kelas & $\mathrm{N}$ & $\begin{array}{c}\text { Nilai } \\
\text { Minimum }\end{array}$ & $\begin{array}{c}\text { Nilai } \\
\text { Maksimum }\end{array}$ & Rerata & Variansi & $\begin{array}{c}\text { Standar } \\
\text { Deviasi }\end{array}$ \\
\hline 1 & Eksperimen & 33 & 55 & 85 & 74,39 & 63,684 & 7,980 \\
2 & Kontrol & 36 & 50 & 80 & 63,75 & 73,393 & 8,567 \\
\hline
\end{tabular}

Berdasarkan tabel di atas, dapat dilihat jumlah responden $(\mathrm{N})$ pada kelas eksperimen sebanyak 33 siswa, rerata kelas ekperimen adalah 74,39, nilai minimum yang diperoleh sebesar 55 sedangkan nilai maksimum sebesar 85 . Sedangkan untuk kelas kontrol jumlah responden sebanyak 36 siswa, rerata kelas kontrol sebesar 63,75 , nilai minimum dan nilai maksimum berturutturut adalah 50 dan 80. Sementara itu variansi yang diperoleh kelas eksperimen yaitu 63,684 dengan standar deviasi 7,980, sedangkan variansi yang diperoleh kelas kontrol yaitu 73,393 dengan standar deviasi sebesar 8,567. Dengan demikian, dapat dikatakan bahwa penyebaran data disekitar rerata untuk kelas eksperimen lebih kecil daripada kelas kontrol. Hal ini menunjukan bahwa data-data untuk kelas eksperimen lebih terkumpul, sedangkan kelas kontrol lebih tersebar luas.

Jika dilihat dengan diagram batang pada gambar 2 diperoleh rerata posttest kelas eksperimen dan kelas kontrol. Berdasarkan diagram batang pada gambar 2, rerata posttest kelas eksperimen lebih besar dari rerata kelas kontrol, ini artinya kedua kelas memiliki kemampuan komunikasi yang berbeda.

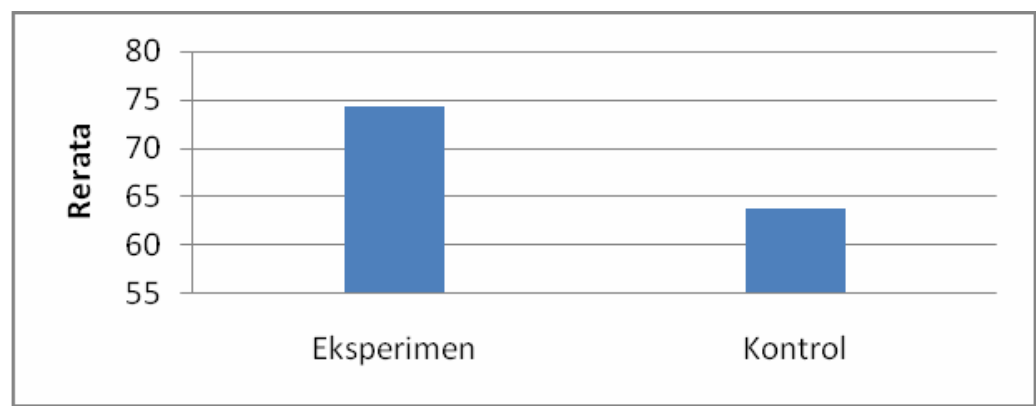

Gambar 2. Diagram Batang Skor Rerata Posttest 


\section{Deskripsi Data Gain}

Dibawah ini merupakan deskripsi N-Gain pada kelas eksperimen maupun kelas kontrol adalah sebagai berikut:

Tabel 4. Deskripsi Data N-Gain

\begin{tabular}{cccccccc}
\hline & & & \multicolumn{5}{c}{ Nilai } \\
\cline { 4 - 8 } No & Kelas & $\mathrm{N}$ & $\begin{array}{c}\text { Nilai } \\
\text { Minimum }\end{array}$ & $\begin{array}{c}\text { Nilai } \\
\text { Maksimum }\end{array}$ & Rerata & Variansi & $\begin{array}{c}\text { Standar } \\
\text { Deviasi }\end{array}$ \\
\hline 1 & Eksperimen & 33 & 0,46 & 0,81 & 0,67 & 0,009 & 0,097 \\
2 & Kontrol & 36 & 0,31 & 0,75 & 0,53 & 0,015 & 0,123 \\
\hline
\end{tabular}

Berdasarkan data yang diperoleh pada tabel di atas dapat dilihat nilai minimum, nilai maksimum dan rerata $\mathrm{N}$-Gain kelas eksperimen lebih tinggi dibandingkan dengan kelas kontrol. Dimana nilai minimum pada kelas eksperimen adalah 0,46 sedangkan pada kelas kontrol adalah 0,31. Nilai maksimum pada kelas eksperimen adalah 0,81 sedangkan pada kelas kontrol adalah 0,75 . Nilai rerata $\mathrm{N}-$ Gain pada kelas eksperimen adalah 0,67 sedangkan pada kelas kontrol adalah 0,53.

Sementara itu variansi yang diperoleh kelas eksperimen yaitu 0,009 dengan standar deviasi 0,097, sedangkan variansi yang diperoleh kelas kontrol yaitu 0,015 dengan standar deviasi sebesar 0,123. Dengan demikian, dapat dikatakan bahwa penyebaran data di sekitar rerata untuk kelas eksperimen lebih kecil daripada kelas kontrol. Hal ini menunjukan bahwa data-data untuk kelas eksperimen lebih terkumpul, sedangkan kelas kontrol lebih tersebar luas.

Perbandingan hasil rerata N-Gain kelas eksperimen dengan kelas kontrol dapat dilihat dari diagram batang di bawah ini:

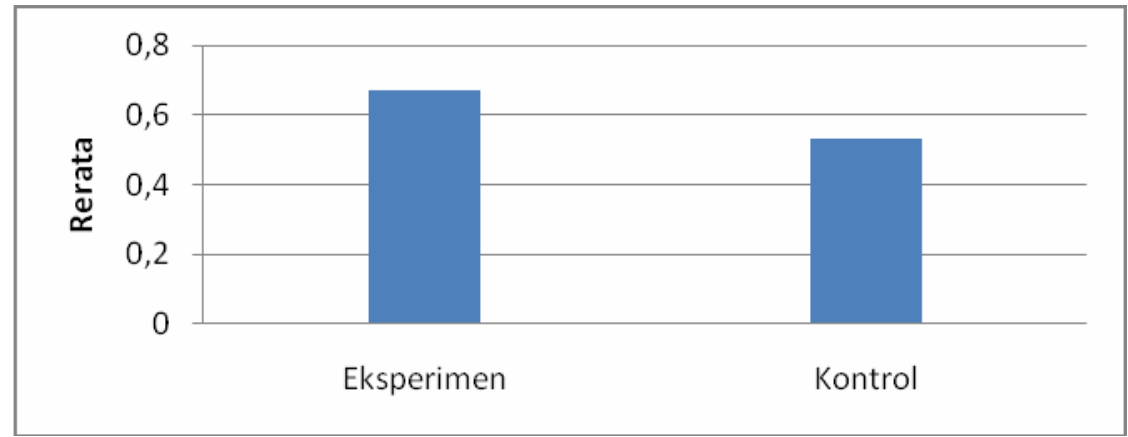

Gambar 3. Diagram Batang Skor Rerata N-Gain

Berdasarkan diagram batang di atas, dapat disimpulkan bahwa rerata $\mathrm{N}$ Gain pada kelas eksperimen lebih tinggi dibandingkan dengan rerata N-Gain pada kelas kontrol. Sehingga dapat dikatakan bahwa kelas eksperimen dan kelas kontrol memiliki perbedaan peningkatan kemampuan komunikasi matematis.

B. Analisis Data

1. Analisis Data Pretest

a) Uji Normalitas

Deskripsi data pretest kemudian dianalisis menggunakan rumus Kolmogorov-Smirnov dalam perhitungan menggunakan program SPSS (Statistical Product and Service Solution) untuk menguji kenormalan data. Jika sig > 0,05 maka data berdistribusi normal dan jika sig < 0,05 dapat 
dikatakan bahwa data tidak berditribusi normal. Hasil uji normalitas pretest kelas eksperimen dan kelas kontrol yang diperoleh adalah sebagai berikut:

Tabel 5. Rekapitulasi Hasil Uji Normalitas Data Pretest

\begin{tabular}{ccccc}
\hline Kelas & $\begin{array}{c}\text { Asymp. Sig. } \\
(2-\text { Tailed })\end{array}$ & $\alpha$ & Keputusan & Keterangan \\
\hline Eksperimen & 0,106 & 0,05 & Terima $\mathrm{H}_{0}$ & Normal \\
Kontrol & 0,141 & 0,05 & Terima $\mathrm{H}_{0}$ & Normal \\
\hline
\end{tabular}

Dari tabel di atas, dapat dilihat bahwa untuk uji normalitas pretest pada kelas eksperimen dan kelas kontrol dengan taraf kepercayaan 5\% ( $\alpha$ 0,05) nilai Asymp. Sig. (2-Tailed) untuk kelas eksperimen 0,106>0,05 dan nilai Asymp. Sig. (2-Tailed) kelas kontrol 0,141>0,05 diperoleh keputusan untuk masing-masing kelas terima $\mathrm{H}_{0}$ yang artinya data berdistribusi normal.

b) Uji Homogenitas

Selanjutnya dilakukan uji homogenitas untuk menentukan kehomogenan sampel. Uji homogenitas digunakan sebagai bahan acuan untuk menentukan uji statistik. Adapun dasar pengambilan keputusan dalam uji homogenitas yaitu jika nilai signifikansi $<0,05$, maka dikatakan bahwa varian dua atau lebih kelompok populasi data adalah tidak sama. Sedangkan jika nilai signifikansi > 0,05, maka dikatakan bahwa varian dari dua atau lebih kelompok populasi data adalah sama.

Berdasarkan hasil uji pretest pada kelas eksperimen dan kelas kontrol, diperoleh hasil yang tertera pada tabel dibawah ini:

Tabel 6. Rekapitulasi Hasil Uji Homogenitas Data Pretest

\begin{tabular}{cccc}
\hline Levene Statistic & df1 & df2 & Sig. \\
\hline .584 & 1 & 67 & .448 \\
\hline
\end{tabular}

Berdasarkan tabel di atas hasil uji homogenitas didapat nilai Sig. adalah 0,448. Keputusan yang diambil adalah terima $\mathrm{H}_{0}$ karena $0,448>$ 0,05. Maka dapat dikatakan bahwa data pretest kelas kontrol dan kelas eksperimen berasal dari varian yang homogen. Setelah data pretest diketahui data normal dan homogen, maka dapat diambil keputusan untuk melakukan uji lanjutan yaitu uji-t Independent 2 Samples. Uji lanjutan ini berguna untuk mengetahui apakah data pretest kelas kontrol dan kelas eksperimen berbeda signifikan atau tidak.

c) Uji-t

Kriteria keputusan uji-t Independent 2 Samples yaitu jika sig $>0,05$ maka terima $\mathrm{H}_{0}$ dan jika sig < 0,05 maka tolak $\mathrm{H}_{0}$. Hasil uji-t kelas kontrol dan kelas eksperimen tertera pada tabel berikut:

Tabel 7. Hasil Uji-t Data Pretest

\begin{tabular}{ccccc}
\hline Jenis Data & Sig. (2-Tailed) & $\alpha$ & Keputusan & Keterangan \\
\hline Pretest & 0,659 & 0,05 & Terima $_{0}$ & $\begin{array}{c}\text { Tidak Terdapat } \\
\text { Perbedaan Signifikan }\end{array}$ \\
\hline
\end{tabular}


Berdasarkan tabel di atas dapat diketahui besarnya Sig. (2-Tailed) adalah 0,659 dengan df $=67$. Diketahui nilai Sig. (2-Tailed) 0,0659>0,05. Dengan demikian, hasil uji-t tersebut menunjukan tidak terdapat perbedaan kemampuan antar kedua kelas sebelum diberikan perlakuan. Dengan kata lain keadaan kedua kelas tersebut sama.

Tidak adanya perbedaan hasil belajar disini terjadi karena saat menjawab soal mereka tidak mengerjakannya dengan sungguh-sungguh, mereka malah lebih banyak bertanya kepada teman disebelahnya, hal ini bisa terjadi karena mereka belum mempelajari materi yang mereka kerjakan. Akan tetapi, jika siswa tersebut bisa mengaitkan materi yang ada dalam soal pretest tersebut dengan pengetahuan yang telah mereka dapat sebelumnya maka siswa akan bisa menjawab soal tersebut tanpa harus bertanya kepada temannya.

2. Analisis Data Posttest

a) Uji Normalitas

Deskripsi data pada posttest selanjutnya diuji normalitas pada kelas eksperimen dan kelas kontrol untuk mengetahui kenormalan data. Uji normalitas dianalisis menggunakan rumus Kolmogorov-Smirnov dalam perhitungan menggunakan program SPSS (Statistical Product and Service Solution) untuk menguji kenormalan data. Jika sig > 0,05 maka data berdistribusi normal dan jika sig < 0,05 dapat dikatakan bahwa data tidak berditribusi normal. Berikut adalah hasil uji normalitas data posttest kelas eksperimen dan kelas kontrol:

Tabel 8. Rekapitulasi Hasil Uji Normalitas Data Posttest

\begin{tabular}{ccccc}
\hline Kelas & $\begin{array}{c}\text { Asymp. Sig. } \\
(2-\text { Tailed })\end{array}$ & $\alpha$ & Keputusan & Keterangan \\
\hline Eksperimen & 0,219 & 0,05 & Terima $\mathrm{H}_{0}$ & Normal \\
Kontrol & 0,254 & 0,05 & Terima $\mathrm{H}_{0}$ & Normal \\
\hline
\end{tabular}

Dari data di atas dapat dilihat bahwa untuk uji normalitas keputusan yang didapat adalah terima $\mathrm{H}_{0}$ untuk kelas kontrol maupun kelas eksperimen dengan taraf kepercayaan 5\% ( $\alpha$ 0,05). Karena nilai Asymp.Sig(2-tailed) untuk kelas eksperimen 0,219>0,05 dan nilai Asymp.Sig(2-tailed) kelas kontrol 0,254 > 0,05. Maka, kedua kelas dapat dikatakan berdistribusi normal.

b) Uji Homogenitas

Selanjutnya dilakukan uji homogenitas untuk menentukan kehomogenan data. Adapun dasar pengambilan keputusan dalam uji homogenitas yaitu jika nilai signifikansi $<0,05$, maka dikatakan bahwa varian dua atau lebih kelompok populasi data adalah tidak sama. Sedangkan jika nilai signifikansi > 0,05, maka dikatakan bahwa varian dari dua atau lebih kelompok populasi data adalah sama.

Berdasarkan hasil uji posttest pada kelas kontrol maupun kelas eksperimen diperoleh hasil dalam tabel berikut:

Tabel 9. Rekapitulasi Hasil Uji Homogenitas Data Posttest

\begin{tabular}{cccc}
\hline Levene Statistic & df1 & df2 & Sig. \\
\hline .639 & 1 & 67 & .427 \\
\hline
\end{tabular}


Berdasarkan tabel di atas hasil uji homogenitas didapat nilai Sig. adalah 0,427 . Keputusan yang diambil adalah terima $\mathrm{H}_{0}$ karena $0,427>$ 0,05 . Maka dapat dikatakan bahwa data posttest kelas kontrol dan kelas eksperimen berasal dari varian yang homogen. Setelah data posttest diketahui data normal dan homogen, maka dapat diambil keputusan untuk melakukan uji lanjutan yaitu uji-t Independent 2 Samples. Uji lanjutan ini berguna untuk mengetahui apakah data pretest kelas kontrol dan kelas eksperimen berbeda signifikan atau tidak.

c) Uji-t

Kriteria keputusan uji-t Independent 2 Samples yaitu jika sig > 0,05 maka terima $\mathrm{H}_{0}$ dan jika sig $<0,05$ maka tolak $\mathrm{H}_{0}$. Hasil uji-t kelas kontrol dan kelas eksperimen tertera pada tabel berikut:

Tabel 10. Hasil Uji-t Data Posttest

\begin{tabular}{ccccc}
\hline Jenis Data & Sig. (2-Tailed) & $\alpha$ & Keputusan & Keterangan \\
\hline Posttest & 0,000 & 0,05 & Tolak $\mathrm{H}_{0}$ & $\begin{array}{c}\text { Berbeda } \\
\text { Signifikan }\end{array}$ \\
\hline
\end{tabular}

Tabel 10 menunjukkan hasil uji-t dimana nilai Sig. untuk data posttest adalah 0,000 . Keputusan yang diperoleh adalah tolak $\mathrm{H}_{0}$ karena $0,000<0,05$, maka data berbeda signifikan. Ini artinya siswa pada kelas kontrol dan kelas eksperimen memiliki kemampuan komunikasi yang berbeda. Dengan demikian, penelitian ini menunjukan bahwa model pembelajaran Giving Question and Getting Answer lebih efektif dalam meningkatkan kemampuan komunikasi matematis siswa daripada model pembelajaran konvensional.

3. Analisis Data N-Gain

a) Uji Normalitas

Data N-Gain kelas kontrol dan kelas eksperimen kemudian dianalisis dengan melakukan uji normalitas, uji homogenitas dan uji lanjutan. Uji normalitas dianalisis menggunakan rumus Kolmogorov-Smirnov dalam perhitungan menggunakan program SPSS (Statistical Product and Service Solution) untuk menguji kenormalan data. Jika sig $>0,05$ maka data berdistribusi normal dan jika sig < 0,05 dapat dikatakan bahwa data tidak berditribusi normal. Berikut ini adalah tabel uji normalitas N-Gain kelas eksperimen dan kelas kontrol.

Tabel 11. Rekapitulasi Hasil Uji Normalitas Data N-Gain

\begin{tabular}{ccccc}
\hline Kelas & $\begin{array}{c}\text { Asymp. Sig. } \\
(2-\text { Tailed })\end{array}$ & $\alpha$ & Keputusan & Keterangan \\
\hline Eksperimen & 0,701 & 0,05 & Terima $\mathrm{H}_{0}$ & Normal \\
Kontrol & 0,613 & 0,05 & Terima $\mathrm{H}_{0}$ & Normal \\
\hline
\end{tabular}

Berdasarkan Tabel 11 di atas uji normalitas N-Gain dengan taraf kepercayaan 5\% $(\alpha 0,05)$ diperoleh nilai Asym. Sig. (2-tailed) untuk kelas eksperimen adalah 0,701 sedangkan pada kelas kontrol adalah 0,613. Kelas eksperimen diperoleh keputusan terima $\mathrm{H}_{0}$ karena nilai Asym. Sig (2-tailed) 0,701 > 0,05 dan untuk kelas kontrol juga diperoleh keputusan terima $\mathrm{H}_{0}$ karena Asymp. Sig (2-tailed) 0,613 > 0,05. Hal ini berarti data pada kelas kontrol dan kelas eksperimen berdistribusi normal. 
b) Uji Homogenitas

Selanjutnya peneliti melakukan uji homogenitas data N-Gain. Uji homogenitas ini berguna untuk menguji kehomogenan data. Adapun dasar pengambilan keputusan dalam uji homogenitas yaitu jika nilai signifikansi $<0,05$, maka dikatakan bahwa varian dua atau lebih kelompok populasi data adalah tidak sama. Sedangkan jika nilai signifikansi $>0,05$, maka dikatakan bahwa varian dari dua atau lebih kelompok populasi data adalah sama. Hasil uji homogenitas kelas eksperimen dan kelas kontrol dapat dilihat pada tabel di bawah ini:

Tabel 12. Rekapitulasi Hasil Uji Homogenitas Data N-Gain

\begin{tabular}{ccccc}
\hline Jenis Data & Sig. & $\alpha$ & Keputusan & Keterangan \\
\hline Posttest & 0,042 & 0,05 & ${\text { Tolak } \mathrm{H}_{0}}$ & Tidak Homogen \\
\hline
\end{tabular}

Dari Tabel 12 di atas dapat kita lihat, untuk uji homogenitas nilai Sig. adalah 0,042 dengan taraf kepercayaan $5 \%(\alpha 0,05)$. Keputusan yang diperoleh adalah tolak $\mathrm{H}_{0}$ karena nilai Sig. adalah 0,042 <0,05, maka dapat dikatakan data N-Gain berasal dari varian yang tidak homogen.

Menurut Jumiati dan kawan-kawan (2011:174) setelah data diketahui normal dan tidak homogen, maka dapat diambil keputusan untuk melakukan uji hipotesis komparatif yaitu uji U Mann-Withney.

c) Uji U Mann-Whitney

Uji hipotesis komparatif ini berguna untuk mengetahui apakah data berbeda signifikan atau tidak. Nilai yang dilihat pada uji ini adalah nilai Sig. (2-tailed) kemudian dibandingkan dengan taraf kepercayaan 5\% ( $\alpha$ 0,05). Jika nilai sig. (2-tailed $)<0,05$ maka data berbeda signifikan, jika nilai sig. (2-tailed) $>0,05$ maka data tidak berbeda signifikan (Jumiati, 2011:174). Berikut adalah hasil uji U Mann- Withney data N-Gain:

Tabel 13. Hasil Uji U Mann-Whitney Data N-Gain

\begin{tabular}{ccccc}
\hline Jenis Data & $\begin{array}{c}\text { Asimp. Sig. } \\
(2-\text { Tailed })\end{array}$ & $\alpha$ & Keputusan & Keterangan \\
\hline N-Gain & 0,000 & 0,05 & Tolak $\mathrm{H}_{0}$ & $\begin{array}{c}\text { Berbeda } \\
\text { Signifikan }\end{array}$ \\
\hline
\end{tabular}

Dari tabel di atas dapat dilihat hasil Uji U Mann-Whitney untuk data $\mathrm{N}$-Gain kelas kontrol dan kelas eksperimen dengan taraf kepercayaan 5\% $(\alpha$ 0,05) diperoleh nilai Asymp Sig. (2tailed) 0,000 < 0,05 berarti berbeda signifikan. Ini artinya siswa pada kelas kontrol dan kelas eksperimen mempunyai perbedaan yang signifikan.

Terjadinya peningkatan hasil N-Gain menunjukan bahwa terjadinya peningkatan kemampuan komunikasi matematis siswa materi aljabar. Peningkatan kemampuan komunikasi matematis siswa antara kelas eksperimen dan kelas kontrol memiliki perbedaan. Dimana kelas eksperimen yang menggunakan model pembelajaran Giving Question and Getting Answer lebih tinggidibandingkan dengan kelas kontrol yang menggunakan model pembelajaran konvensional.

\section{PEMBAHASAN}

Penelitian ini bertujuan untuk meningkatkan kemampuan komunikasi matematis siswa menggunakan model pembelajaran Giving Question and Getting 
Answer di SMP Negeri 1 Cinangka pada materi aljabar. Sebelum penelitian dilakukan, peneliti terlebih dahulu melakukan uji coba instrumen kemudian dianalisis untuk mengukur validitas, reliabilitas, taraf kesukaran, dan daya pembeda soal. Instrumen penelitian yang digunakan dalam penelitian ini adalah instrumen yang mengukur kemampuan komunikasi matematis. Sampel dalam penelitian ini adalah kelas VIII F sebagai kelas eksperimen yang berjumlah 33 siswa dan kelas VIII G sebagai kelas kontrol yang berjumlah 36 siswa. Penelitian dilakukan sebanyak enam kali pertemuan untuk kelas eksperimen dan enam kali pertemuan untuk kelas kontrol ditambah dengan pretest untuk mengukur kemampuan awal siswadan posttest untuk mengukur kemampuan akhir siswa.

Setelah diberi perlakuan yang berbeda pada kedua sampel, kemudian data pretest, posttest dan $\mathrm{N}$-Gain dianalisis untuk menunjukan adanya peningkatan kemampuan komunikasi. Hal ini dapat dilihat dari peningkatan hasil belajar pada kelas eksperimen yang menggunakan model pembelajaran Giving Question and Getting Answer dibandingkan dengan kelas kontrol yang menggunakan model pembelajaran konvensional.

Hasil rerata pretest untuk kelas eksperimen adalah 21,67 dan kelas kontrol adalah 22,64. Tidak terdapat perbedaan yang besar antara hasil pretest kelas eksperimen dan kelas kontrol pada waktu diberikan pretest, ini berarti kemampuan awal siswa relatif sama. Setelah dilakukan pretest selanjutnya kelas ekperimen diberi perlakuan menggunakan model pembelajaran Giving Question and Getting Answer dan kelas kontrol diberikan perlakuan model pembelajaran konvensional. Untuk mengetahui hasil perlakuan tersebut dilakukan posttest untuk mengetahui keadaan akhir yang selanjutnya dihitung dan dianalisis sehingga didapat rerata hasil posttest kelas eksperimen adalah 74,39 dan kelas kontrol adalah 63,75. Berdasarkan analisis uji-t skor posttest antar kelompok diperoleh nilai Sig. (2-Tailed) sebesar 0,000 pada taraf signifikan 0,05. Nilai Sig. (2-Tailed) pada taraf signifikansi 0,05 atau $(0,000<0,05)$. Sehingga dapat disimpulkan bahwa terdapat perbedaan signifikan kemampuan komunikasi matematis siswa antara kelas eksperimen dan kelas kontrol.

Nilai N-Gain yang diperoleh kelas eksperimen lebih tinggi dibandingkan dengan kelas kontrol. Terbukti pada hasil uji $U$ Mann-Whitney diperoleh nilai Asymp Sig. (2tailed) 0,000 $<0,05$ berarti berbeda signifikan. Ini artinya siswa pada kelas kontrol dan kelas eksperimen mempunyai perbedaan yang signifikan. Maka $\mathrm{H}_{0}$ ditolak dan $\mathrm{H}_{\mathrm{a}}$ diterima yang berarti penerapan model penbelajaran Giving Question and Getting Answer dapat meningkatkan kemampuan komunikasi matematis siswa kelas VIII SMP Negeri 1 Cinangka.

\section{SIMPULAN DAN SARAN}

Berdasarkan penelitian yang telah dilakukan, dapat disimpulkan bahwa penerapan model pembelajaran Giving Question and Getting Answer dapat meningkatkan kemampuan komunikasi matematis siswa kelas VIII SMP Negeri 1 Cinangka. Hal ini dapat dilihat dari hasil N-Gain. N-Gain pada kelas eksperimen yaitu sebesar 0,67 termasuk kedalam kategori sedang dan N-Gain kelas kontrol yaitu sebesar 0,53 termasuk dalam kategori sedang.

Nilai N-Gain yang diperoleh kelas eksperimen lebih tinggi dibandingkan dengan kelas kontrol. Hal ini dibuktikan pada hasil uji U Mann-Whitney diperoleh nilai Asymp Sig. (2tailed) $0,000<0,05$ berarti berbeda signifikan. Ini artinya siswa pada kelas kontrol dan kelas eksperimen mempunyai perbedaan yang signifikan. Maka $\mathrm{H}_{0}$ ditolak dan $\mathrm{H}_{\mathrm{a}}$ diterima yang berarti penerapan model penbelajaran Giving Question and Getting Answer dapat meningkatkan kemampuan komunikasi matematis siswa kelas VIII SMP Negeri 1 Cinangka. 


\section{DAFTAR RUJUKAN}

Hendriana, H., Sumarmo, U. dan Rohaeti, E. E. (2013). Kemampuan Komunikasi Matematik Serta Kemampuan dan Disposisi Berpikir Kritis Matematik. Delta-Pi Jurnal Matematika dan Pendidikan Matematika, 2 (1), (Online), (http://ejournal.unkhair.ac.id/index.php/deltapi/article/ view/97/65, diakses 3 Agustus 2013)

Iswadi, H. (2016). Sekelumit Dari Hasil PISA 2015 Yang Baru Dirilis. (Online), (http://www.ubaya.ac.id/2014/content/articles_detail/230/ Sekelumit-Dari-Hasil-PISA-2015-Yang-Baru-Dirilis.html, diakses 10 April 2017).

Oktaviyanthi, R. dan Herman, T. (2016, Oktober). A Delivery Mode Study: The Effect of Self-Paced Video Learning on First-Year College Students' Achievement in Calculus. Artikel dipresentasikan pada The $4^{\text {th }}$ International Conference on Quantitative Sciences and Its Applications, Universiti Utara Malaysia, Putrajaya, Malaysia. (Online) (http://aip.scitation.org/doi/abs/10.1063/1.4966102, diakses 11 Desember 2017).

Oktaviyanthi, R., Agus, R. N. dan Supriani, Y. (2015). Pisa Mathematics Framework dalam Penelusuran Mathematical Literacy Skills Mahasiswa. Jurnal Ilmu Pendidikan STKIP Kusuma Negara, (7) 1, hlm. 77-85, (Online), (https://osf.io/preprints/inarxiv/z2qsf/, diakses 11 Desember 2017).

Oktaviyanthi, R., Agus, R.N. dan Safaah, E. (2017). Perspektif Guru Matematika SMP dan MTS Swasta pada Pemanfaatan Mathematics Education Software. Artikel dipresentasikan pada Seminar Nasional Riset Terapan 2017, Universitas Serang Raya. (Online), (http://ejurnal.lppmunsera.org/index.php/senasset/article/view/454/480, diakses 30 Desember 2017).

Oktaviyanthi, R., Safaah, E. dan Agus, R.N. (2017). Pemberdayaan Keterampilan Guru Matematika dalam Menyusun Bahan Ajar Berbantuan Mathematics Education Software. Jurnal Pengabdian Masyarakat Wikrama Parahita, 1 (1), 19-24. (Online), (http://ejurnal.lppmunsera.org/index.php/parahita/article/view/270/523, diakses 30 Desember 2017).

Oktaviyanthi, R. dan Dahlan, J.A. (2018). Developing Guided Worksheet for Cognitive Apprenticeship Approach in Teaching Formal Definition of the Limit of A Function. IOP Conference Series: Materials Science and Engineering $335 \quad$ (1), $012120 . \quad$ (Online), (http://iopscience.iop.org/article/10.1088/1757-899X/335/1/012120/pdf, diakses 26 April 2018).

Sugiyono. (2015). Metode Penelitian Pendidikan (Pendekatan Kuantitatif, Kualitatif, dan $R \& D)$. Bandung: ALFABETA.

Suherman, E. (2001). Common Text Book STRATEGI PEMBELAJARAN MATEMATIKA. Bandung: JICA.

Surya, M. (2004). Psikologi Pembelajaran Dan Pengajaran. Bandung: Pustaka Bani Quraisy.

Susanto, A. (2013). Teori Belajar \& Pembelajarandi Sekolah Dasar. Jakarta: Kencana.

Syamsuddin, A. (2009). Psikologi Kependidikan Perangkat Sistem Pengajaran Modul. Bandung: Remaja Rosdakarya. 